\title{
AN APPRAISAL ON THE OBLIGATION OF COMPANIES TO PAY ZAKAT: THE MALAYSIAN LAW AND SHARIAH PERSPECTIVES
}

\author{
Nazri Ramli ${ }^{1}$ \\ Faculty of Laws and International Relations, \\ Universiti Sultan Zainal Abidin (UNiSZA), Malaysia \\ (Email: nazriramli87@gmail.com; s12539@putra.unisza.edu.my) \\ Zuhairah Ariff Abdul Ghadas ${ }^{2}$ \\ Professor of Laws, Faculty of Laws and International Relations, \\ Universiti Sultan Zainal Abidin (UNiSZA), Malaysia \\ (Email: zuhairahariff@unisza.edu.my)
}

Accepted date: $22-02-2019$

Published date: 10-07-2019

To cite this document: Ramli, N. \& Abdul Ghadas, Z, A. (2019). An Appraisal on The Obligation of Companies to Pay Zakat: The Malaysian Law and Shariah Perspectives. International Journal of Law, Government and Communication, 4(15), 08-17.

DOI: $10.35631 /$ ijlgc.415002

\begin{abstract}
Zakat is one of the five pillars of Islam, obligatory upon human beings who believe in Allah and His Messenger (pbuh). It refers to the determined share of wealth prescribed by Allah as an act of worship to be distributed to a certain group of beneficiaries (al-Asnaf). The consideration of its great objectives (al-Maqasid) in Islam, among others, public interest and social justice to the Muslim society influences contemporary Muslim jurists to uphold the obligation of companies to pay zakat as issued in their fatwas and resolutions. In Malaysia, several fatwas and resolutions issued by the religious fatwa councils clearly impose this religious obligation on the corporations as their business zakat (Urudh al-Tijarah) which are legally registered under the Companies Act 2016. This paper discusses the obligation of companies to pay zakat from Malaysian law and Shariah perspectives. It aims to analyse whether it is legally viable for corporations registered under the Companies Act 2016 which adopts the English common law to be obligated to pay zakat. The finding shows that the current legal structure of a corporation does not conform to the Shariah principles in relation to zakat obligation. It demands for certain modifications to the current framework and hence, the current fatwas in imposing zakat on the corporations in Malaysia are proposed to be reviewed and revisited. Research methodology applied in this paper are doctrinal and statutory analysis.
\end{abstract}

Keywords: Companies, Zakat, Malaysia, Shariah

\section{Introduction}

Zakat is an act of worship performed to draw closer to Allah by extracting an obligation right from certain kinds of wealth and giving it to specified groups at a specified time, in accord 
with specific conditions. It is one of the five pillars of Islam and is obligatory upon every Muslim for whom its requisite conditions are fulfilled or met. (Bouheraoua, 2012)

Contemplating the great objectives (al-Maqasid) of zakat ruling in helping the needy and the poor has led several fatwas and resolutions held by some Islamic fatwa organizations around the world including Malaysia to uphold that the "Shariah-compliant" companies, registered under the common law statute, are obligated to pay zakat on their businesses as the corporate wealth is tainted with their rights. Prior to the existence of these fatwas, the contemporary Muslim jurists had discussed on the permissibility of corporations under the Shariah and viewed that the doctrine of corporate personality (al-Shakhsiyyah al-I'tibariyyah) of a company as a legal person is well accepted under the principle of Maslahah (interest) particularly for matters relating to businesses- in making references to the traditional Islamic religious institutions, such as waqaf, baitul mal (public treasury), mosque, and the like. (Nyazee, 2010)

In Malaysia, the Muslim jurists adopted the same approach in holding that the corporations are subject to the zakat payment and subsequently issued several fatwas in relation to it. The fatwas in imposing the corporations to pay zakat here expressly refer to the corporations registered under the Companies Act 2016 which is embodied from the common law and the conventional English company law. (Mohamad, 2012) Section 3 of the Companies Act 2016 defines corporation as any body corporate formed or incorporated or existing in Malaysia or outside Malaysia and includes any foreign company, limited liability partnership and foreign limited liability partnership. The subsequent provisions in the Act entail its classification into subsidiary and holding company, ultimate holding company, whollyowned subsidiary, private and public company and so on.

As such, this paper will examine the obligation of companies or corporations to pay zakat from Shariah and the Malaysian Law perspectives respectively. Specifically, this paper focuses on the viability of corporations incorporated under the Companies Act 2016 that adopts common law and considers it as a fictitious legal entity to pay zakat as religious obligation that is originally imposed on individual human beings under the Shariah. Other issues such as the misconception of company and partnership that influenced the current fatwas in imposing zakat on the corporations in Malaysia and possible constitutional issue arising from such fatwas are also analysed.

\section{Doctrine of Corporate Personality}

Company or corporation is a business vehicle, which is established under the doctrine of corporate personality. Corporate personality is an entrenched legal principle of the English company law. Under this doctrine, a company is recognized as a legal person and has distinguished legal features, namely a legal entity separated from its members, perpetual succession, right to enter into legal proceedings, and deals with property under its own name and ability to limit the liability of its members. (Hassan, Abdul Ghadas \& Abdul Rahman, 2012)

The doctrine of separate legal entity was first introduced by the English common law through the decision of the House of Lords in the case Salomon v. Salomon \& Co. Ltd. (1897) where the court held that despite Mr. Salomon having the control over the company, it was neither his agent nor trustee (Zuryati, Yusuff \& Azree, 2009). Thus, under the law, person has two kinds; namely the natural persons or human beings, and the artificial person or a legal entity (Abdul Ghadas \& Abdul Aziz, 2017). 


\section{Company Laws in Malaysia}

In Malaysia, the Companies Act 2016 (repealing the then Companies Act 1965), which is modelled on both the English Companies Act 1948 and the Australian Uniform Companies Act 1961, clearly incorporated the English law doctrine of corporate personality. Under the Companies Act 2016 (Act 777), section 20 (a) provides that a company incorporated under this Act is a body corporate, and shall have legal personality separate from that of its members. Section 21 further illustrates that it shall be capable of exercising all the functions of a body corporate. According to Salleh Abas FJ, it is 'artificial' the company's legal persona is the result of statutory acts of the Registrar of Companies under s. 16 of Companies Act 1965. (Tan Lai v. Mohamed Bin Mahmud [1982]) (Hassan, Abdul Ghadas \& Abdul Rahman, 2012)

There are many case laws that underline the legal features of a body corporate. Firstly, regarding the separate legal entity doctrine, the Court of Appeal in Lee Eng Eow (as director of Lee Guat Cheow \& Co Sdn Bhd) v Mary Lee (as executrix of the estate of Low Ai Lian) \& Ors [1999] held that an association has a legal personality of its own apart from the persons who comprise it. If a director breached his duty, the company has the right to take legal action against him. A member of the company cannot sue on the company's behalf to enforce a company's rights. This rule is known as the 'proper plaintiff rule' or the rule in Foss v. Harbottle (1843). Secondly, a company also has perpetual succession. In Abdul Aziz Bin Atan v. Ladang Rengo Malay Estate Sdn. Bhd. A [1985], the court held that although there are changes in the membership, the corporate entity continues unchanged. In Re Noel Tedman Holdings Pty Ltd [1967], the court held that a company may even continue to exist despite the death of all its shareholders and directors.

Thirdly, a company also has the power to hold land. Section 21 (1) (b) of the Companies Act 2016 provides that a company shall have capacity to acquire, own, hold, develop or dispose of any property. (Zuryati, Yusuff \& Azree, 2009) The property will be treated as the company's own and not the shareholder. Therefore, even if a person owns all the shares in the company, he does not own the company's property nor does he have any legal or equitable interest therein (Macaura v. Northern Assurance Co. Ltd. [1925]). Next, ability to limit the liability of members is another attribute of a company (section 10(2) of Companies Act 1965). In a company limited by shares, its member has either fully paid up on his shares or otherwise. In fact, where a member of a limited company has fully paid up on his shares, the general principle is that he will not be liable for the debts of the company. (Meng, 2017)

\section{Companies as a Legal Entity from Shariah Perspective}

Under Shariah law, discussion on corporate personality is derived from the views of the contemporary Muslim jurists (fuqaha) on the entity of artificial person (al-Shakhsiyah alI'itbariyah) (Abd Ghadas \& Wan Hussin, 2008). Most of them claimed that this concept was known to Islamic law, while some are doubtful whether this concept, in fact exists in Islamic law (Nyazee, 1997). According to Nyazee, the earlier Muslim jurists were aware with the concept of corporate personality but rejected it because of the system, which they were dealing with. Nyazee contended that this nevertheless does not mean that the Islamic law totally rejects the concept. Since the early days of development in fiqh, there were many evidences, which show that the concept of fictitious person had been applied. For example the recognition of waqf, bayt-a- mal and the mosque as an entity. According to the modern jurists of fiqh, such as Sheikh Mustafa Ahmad al-Zarqa and Sheikh Muhammad Abu Zuhrah, the theory which recognizes an entity other than human being as a legal person can be justified through the theory of fiqh known as al-Dhimmah. (Hassan, Abdul Ghadas \& Abdul Rahman, 2012) 
Al-Dhimmah is a term used in theories of fiqh used by the fuqaha to resolve issues relating to al- Iltizamat (obligation) and al-Ahliyyah (capacity). The concept of al-Dhimmah is not new as it had been commonly applied and discussed by the fiqh jurists since the early era of development of fiqh theories. (Abd Ghadas \& Wan Hussin, 2008) Majority of the contemporary fuqaha have accepted and acknowledged the existence of an entity other than a human being which is entitled to some rights and liable to certain obligations and responsibilities but different from the English law, discussion of the fuqaha on artificial person does not only lie in the entity of the fictitious person but also whether it is subject to obligation and responsibilities as required under Shariah.

However, according to Zuryati, Yusuff \& Azree (2009), the discussion of al-Dhimmah to an artificial entity is heavily criticized by the majority of the past Muslim jurists. According to them, al-Dhimmah refers to anything which has attributes of human being which shall denote to his rights. They take the view that al-dhimmah is a 'dzat' which is real and cannot be fictitious because the Shariah only imposes obligations and rights on a real person and not others. (Hassan, Abdul Ghadas \& Abdul Rahman, 2012)

\section{The Concept of Zakat In Shariah Law}

Zakat is defined as an act of worship performed to draw closer to Allah by extracting an obligation right from certain kinds of wealth and giving it to specified groups at a specified time, in accord with specific conditions. (Bouheraoua, 2012) It is also used to mean the action of payment of this share. According to al-Nawawi's report form al-Wahidi, this share of wealth is called zakat because it increases the funds from which it is taken and protects them from being lost or destroyed. Ibn Taimiyah said that the inner soul of the zakat payer becomes better and his wealth becomes cleansed. (Al-Qaradawi, 2000)

Zakat is one of the five pillars of Islam and is obligatory upon every Muslim for whom its requisite conditions are fulfilled. Shariah jurists all agree that for a free, sane, adult Muslim who knows that zakat is an (religious) obligation, whether male or female, zakat is obligatory on his/her wealth if it reaches the minimum limit (nisab), if the owner has the ability to pay, and if the necessary conditions are met. (Bouheraoua, 2012) Its legislation has been established in the Qur'an, the Sunnah. Allah indeed says:

"Establish prayer and pay zakat and whatsoever good you send before you for your souls, you will find it with Allah" (2:110)

Allah also says:

"Take alms of their wealth, wherewith you may purify them and may make them grow" (9: 103)

Ibn Abbas narrated that when the Messenger of Allah pbuh sent Muadh to Yemen, He said: invite them to testify that none is worthy of worship but Allah and that I am the Messenger of Allah. If they comply with that, then inform them that Allah has made prayer obligatory upon them five times during each day and night. If they comply with that, then inform them that Allah has made charity obligatory upon them in their wealth. It is to be taken from their rich and distributed among their poor. (Sahih Al-Bukhari, 1:2, hadith no. 8)

As for zakat, it is not purely a worship, for in addition to being a worship it is a defined right of the poor, an established tax, and an ingredient of the social, and economic system of the society. (Al-Qaradawi, 2000) Due to these maqasid (objectives) of zakat, and wealth expansion, Scholars view that company's wealth is also inclusively zakatable taking into 
account the maslahah (interest) and justice to the Muslim society. (Abu Bakar \& Abdul Rashid, 2010)

\section{The Obligation of Corporations to Pay Zakat}

The contemporary Muslim jurists held different opinions on the types of companies subject to zakat into two views. Firstly, Sheikh Abdul Rahman Isa and Dr. Wahbah al-Zuhaili view that the zakat imposition on a corporation depends on its type of business. If it is a mere manufacturing purpose which does not conduct any business practices, it is herein not subjected to the zakat except for its profit, and subsequently such profit is combined with the shareholder's wealth and he pays it accordingly. If the company is a business type in nature, any gains of it are zakatable as a business zakat. Secondly, according to Sheikh Muhammad Abu Zuhrah, Abdul Wahab Khalaf, Abdul Rahman Hasan, and Dr Yusuf al-Qaradawi, zakat is imposed on the company's shares regardless of its status as an issuing-shares company. The shares are treated as a business stock (Urudh al-Tijarah), which is zakatable. (Al-Soifi, 2006)

Next, according to Said Bouheraoua (2012), there is no disagreement among scholars that a company's wealth is subjected to zakat except on the right person who is obligated to pay it, be it the company itself of its shareholders. There are three views on the obligation of company as a fictitious person to pay zakat similar to a human being. This first view is adopted by jurists such as, Sheikh Ali al-Khafif, Mustafa al-Zarqa, Ahmad Muhammad alKhuli and Mahyuddin Ali al-Qurahdaghi. According to this view, a company is recognized as having complete legal capacity (al-Ahliyyah) and as such obligated to pay zakat on its own behalf. The corporation pays zakat based on the nature of the business activity and without a need to look at the intention of the shareholders. The grounds of this view are as follows:

1. Full consideration to the concept of legal entity bestowing upon it both ahliyyah alAda' (the capacity for performance of duties) and ahliyyah al-Wujub (the capacity for acquisition of rights). They considered it as an independent entity from its shareholders;

2. Analogy with the principle of khultah (mingling) as mentioned in the hadith of the prophet pbuh narrated by Sayyidina Abu Bakr r.a which means; "The property of different (owners) should not be joined; nor should joint property be split for fear of (paying more or receiving less) zakat." (Sahih Al-Bukhari, 2:526 hadith no. 1382);

3. Its harmony with the law of corporations in the Muslim countries; and

4. Its harmony with the fatwa that requires zakat to be paid on salaries when they reach the nisab.

Under the second view, which is supported by the International Islamic Fiqh Academy in its Resolution No. 28 (3/4) and jurists such as Sheikh al-Darir, Dr. Wahbah al-Zuhaili, Sheikh Said Ramadhan al-Buti and others, it stipulates that the shareholders are the only persons who are mandated to pay zakat since the company has no religious obligation. This view accepts a legal entity having ahliyyah al-Wujub but not ahliyyah al-Ada'. They made eligibility for moral responsibility (taklif) the condition for ahliyyah al-Ada' and that is only realized when one has the ability to understand the message addressed to one. Thus, they took the view that the shareholders have the original obligation to pay zakat but they may assign the company to act as their representative and pay it on their behalf. Their evidence includes the following:

1. The communication from the Lawgiver that demands performance or avoidance of acts is not addressed to legal entities, but rather, to the individuals affiliated with 
them. This is because the hukm taklifi is the message of Allah related to the acts of mukallafs and legal entities are not mukallaf;

2. Applicability of the hukm taklifi has two conditions; first, the ability to understand the evidence that conveys the demand, an ability which is realized by rational capacity and rational capacity is normally associated with puberty. Second, the mukallaf must be fit for what is demanded if him/her; and

3. All the topics investigated with relation to the hukm taklifi (by scholars of usul fiqh) are related to human beings, and ahliyyah al-Ada' cannot possibly be realized except by human beings, even though this capacity may be impaired. Due to this, it is missing in the legal entity-the corporation.

On the other hand, the resolution of the International Islamic Fiqh Academy further states that the company will pay the shareholders' zakat on shares, on behalf of the shareholders under the following circumstances:

1. If such obligation is stated in the company's article of association,

2. Agreed upon during the company's general meeting,

3. If there is any existing law requiring the company to pay zakat, or

4. If there is an authorization from the shareholders for the company to pay zakat on their behalf. (Hassan A., 2013)

The third view is supported by jurists such as Sheikh al-Mawdudi, and al-Qaradawi. Under this view, zakat is obligatory upon the corporation and its legal entity status is given consideration if the State's legal system imposes the obligation to pay zakat upon the corporation. The basis of their opinion is reliance to the fiqh maxim: "the Muslim ruler's decision puts an end to dispute." Imam al-Qarafi, the Maliki scholar, in explaining this maxim states:

"Know that the ruling of a judge (a ruler) in ijtihadi issues ends disputes, one holding an opposing view foregoes his own view for the view of the ruler, and his fatwa after the judge's ruling changes from what he previously used to say on the matter. This is the correct view among the opinions of scholars."

\section{Observation}

It is observed that all the views of the contemporary Muslim scholars share similarity in that the wealth of the corporations are zakatable as a busines stock (urudh al-Tijarah) based on the concept of maslahah and maqasid of zakat itself. The only difference between them is the right person or zakat payer who is obligated to pay it as a religious obligation which results into three views. According to the first view, they treat a company or a fictitious legal entity as a real person similarly like other human beings having mandate to pay zakat by possessing both ahliyyah al Ada' and ahliyyah al-Wujub. Meanwhile, the second view looks at the obligation of zakat from the ruling (hukm taklifi) perspective or the message (khitab) of the rulings from the Lawgiver which is only confined to human beings. This is because the alDhimmah concept is only available through insaniyyah (being a natural person) from which the human being is prepared to potentially accept the aql (intellect) and as a consequence of which the nature of obligation or taklif is understood. As such, they prefer the shareholders as the human beings are the one who are obligated to pay zakat, particularly zakat on their own shares instead of the company because the latter has no religious mandate or dhimmah. However, they consider the company be required to pay zakat on their behalf if there is an express provision found in the law statute, memorandum of association or resolution of the board. Lastly, the third view imposes zakat on the companies based on the legal system of a state which clearly imposes zakat on the companies. This is somehow closely connected to 
the concept of as-Siyasah as-Syariyyah (public-policy ruling) which is the government policy introduced by the ruler. Nonetheless, neither of these views proposes a holistic amendment to the current legal framework of such corporations for the purpose of zakat imposition.

\section{Perspectives of the Malaysian Law}

Under the Federal Constitution, zakat is treated as an Islamic law matter that falls under No. 1, Item II, State List of the $9^{\text {th }}$ Schedule. It states as follows: "Islamic law, personal and family law of persons professing the religion of Islam, including the Islamic law relating to...zakat, fitrah and Baitulmal (public treasury) or similar Islamic religious revenue”. In addition, in relation to grants and revenues assigned to states, item 13, Part III of the $10^{\text {th }}$ Schedule clearly mentions that zakat, fitrah or other Islamic revenues are among the sources of revenue assigned to the respective states. Uniquely, Article 97 (3) of the Federal Constitution provides that if any zakat is raised, it shall be paid into a separate fund from the consolidated funds of a state as provided under paragraph (2) of the Article. In short, zakat is a state revenue and each state authority shall have authority over zakat funds.

The body being responsible for the administration of zakat is the Islamic religious councils of each state. For example, the Selangor State Islamic Religious Council or Majlis Agama Islam Selangor (MAIS), a body corporate established under Section 5(1) of the Administration of The Religion of Islam (State of Selangor) Enactment 2003 ("the Enactment") is responsible for the collection and administration of zakat in the State of Selangor by virtue of Section 86 of the Enactment. It has also power to introduce rules, procedures as well as policies pertaining to zakat. (Section 87 of the Enactment)

The obligation of companies to pay zakat in Malaysia arises after several fatwas at national and state levels together with research papers in imposing zakat on companies as a corporate zakat on its businesses were already resolved. Reference to this can be made firstly, to the $31^{\text {st }}$ Muzakarah (Conference) of the Fatwa Committee National Council of the Islamic Religious Affairs Malaysia or Jabatan Kemajuan Islam Malaysia (JAKIM) held on $9^{\text {th }}$ December 1992 which resolved that a business company (registered under the then Companies Act 1965) is obligated to pay zakat fulfilling these six conditions which are as follows:

1. The company is owned by Muslims;

2. The company is owned by free Muslims;

3. Complete ownership;

4. The amount of wealth reaches the minimum zakatable limit (nisab);

5. The wealth possessed is for one lunar year (hawl); and

6. The zakat rate on company is $2.5 \%$. (Mohamad \& Trakic, 2013)

As for the company shared by Muslims and non-Muslims, only the shares owned by Muslims are zakatable. Secondly, this fatwa is consistently parallel to the resolution of fatwa of Selangor dated 24 July 2001 which entails that zakat is obligatory only on the shares of Muslims in a company whose shareholders are mixed between Muslims and non-Muslims.

However, this fatwa shall only be binding on the individual Muslims excluding the companies. This is evidenced through Section 49(1) of the Enactment which expressly provides that upon its publication in the Gazette, a fatwa shall be binding on every Muslim in the State of Selangor as a dictate of his religion and it shall be his religious duty to abide by and uphold the fatwa, unless he is permitted by Hukum Syarak to depart from the fatwa in matters of personal observance. The word "Muslim" here is clearly defined under Section 2 (a) of the Enactment as a person professing the religion of Islam. 


\section{The Legal Issues}

The fatwas and resolutions obligating companies to pay zakat have resulted into conflict of a few shariah and legal issues which remain confusing, uncertain and ambiguous and demand more clarifications. (Mohamad, 2012) Firstly, the dilemma of fully recognizing the doctrine of separate legal entity of corporations to be part and parcel to the Shariah law and whether this requires modifications or otherwise. Contemporary Muslim Jurists held different opinions on this matter. Some jurists such as the Majlisul Ulama of South Africa totally oppose this doctrine simply because it is originated from the capitalist system of western economists untenable to Shariah principles. (Hassan, Abdul Ghadas \& Abdul Rahman, 2012) In contrast, some of them give full recognition of this doctrine in making special reference to several classical Islamic institutions like waqf, masjid, baitul mal and others. (Uthmani, 2008) Be that as it may, this group of scholars held different opinions on the right person who needs to pay zakat. Since some of them have realized company as a fictitious person and zakat as a ruling or hukum taklifi revealed from Allah upon human beings having al-Dhimmah or taklif, zakat ruling is only obligatory upon the shareholders' wealth or shares. (Al-Ghufaili, 2008) As opposed to this, some group of scholars such as Sheikh Dr. Mahyuddin al-Qurahdaghi and others viewed that there is no impediment to impose zakat on the corporations after giving full recognition to their status as the legal entities under the Shariah and thus their obligations to pay zakat is similarly akin to the individual human beings. (Al-Qurah Daghi, 2011) According to Nyazee, (2010) although this doctrine is accepted under the shariah, it demands for a certain modifications such as the company shall have no religious obligations (alDhimmah) which are only imposed on human beings such as zakat, charity and the like. As such, he firmly views that the zakat is only imposed on the wealth of the shareholders.

This issue is very crucial since the above fatwas though are silent on which opinion was adopted in arriving such fatwas, seem to adopt the view that a company as a legal entity is subject to zakat payment. Nonetheless, the scholars in Malaysia have overlooked the company from Shariah perspectives, as a fictitious person registered under the Companies Act 2016 which is embodied from the common law and the conventional English company law and thus fully enjoys the doctrine of separate legal entity having its own liability separated from its members. (Zuryati, Yusuff \& Azree, 2009) In addition, this legal doctrine is introduced for "the purpose of fostering business development by allowing owners to invest in a venture without being personally liable in tort or contract law for the company." (Mohamad, 2012)

Secondly, the misconception of Malaysian scholars between company and partnership which both have a great differences under the law has resulted into viewing that a company is obligated to pay zakat by looking at its shareholders who are individual Muslims.(Mohamad, 2012) This view seems to neglect the above doctrine and remains inconsistent with it and as such imputing the religion of the shareholders to the company's obligation to pay zakat is impossible and defeats the separate legal entity doctrine. In addition, in some cases, shareholders may be among corporate entities instead of human beings. (Mohamad, 2012)

Next, imposing zakat on companies is viewed unconstitutional under the Federal Constitution due to the fact that the Constitution only permits zakat (which falls under the state list) to be levied on "persons professing the religion of Islam". Any attempt to levy zakat otherwise that on "persons professing the religion of Islam", including companies (which fall under the federal list) is not legally possible. (Mohamad, 2012) In fact, under the common law, a corporation has no religion and does not ever profess the religion. (Potensi Bernas Sdn Bhd v. Datu Badaruddin Datu Mustapha [2009] 8 CLJ 573) In addition, such fatwas are only 
binding-if they are later published in the Gazette- on the individual Muslim believers excluding the companies as the corporate legal entities.

\section{Conclusion}

A maelstrom of Shariah and legal issues arising from the fatwas in imposing the corporations to pay zakat in Malaysia necessitates these fatwas to be reviewed and revisited in order to comply with the current legal framework of corporations under the Companies Act 2016 as well as the Federal Constitution. Furthermore, it is also proposed that the existing legal framework of the corporations demands for modification in order to be consistently in line with the Shariah principles, particularly in relation to zakat imposition. In fact, a company shall have no religious mandate or obligation like zakat, charity and the like since it is confined to the Muslim individuals professing the religion of Islam. For the legality of zakat imposition under the Federal Constitution, it is suggested that an amendment to a few legal statutes at both federal and state levels is necessary and should corporate zakat as paid by legal entities be clearly distinguished from zakat of individual persons professing the religion of Islam as laid down under the State List of the constitution.

\section{References}

Abdul Ghadas, Z. A., \& Abdul Aziz, H. (2017). Legal Framework of Shariah Corporations in Malaysia: Special References to Waqf Corporation. Journal of Modern Accounting and Auditing, Vol. 13, No. 3.

Abdul Ghadas, Z. A., \& Wan Hussin, W. R. (2008). The Myth of Corporate Personality: An Overview from the English Law and Shariah. Shariah Law Reports Articles [2008] ShLR xiii.

Abu Bakar, N. B., \& Abdul Rashid, H. M. (2010). Motivations of Paying Zakat on Income: Evidence from Malaysia. International Journal of Economics and Finance, Vol. 2, No.3.

Al-Ghufaili, A. A. M. (2008). Nawazil Al-Zakat, Dirasat Fiqhiyyah Ta'siliyyah Limustajaddat Al-Zakat. Bank Al-Bilad.

Al-Soifi, A. A. (2006). Al-Syarikah Al-Qobidah Wa Ahkamuha fi Al-Fiqh Al-Islami. Jordan: Dar Al-Nufas.

Al-Qaradawi, Y. (2000). Fiqh Al-Zakat: A Comparative Study of Zakat, Regulations and Philosophy in the Light of Al-Quran and Al-Sunnah. Jeddah, Kingdom of Saudi Arabia: Scientific Publishing Centre, King Abdul Aziz University, Vol. 1.

Al-Qurah Daghi, M. (2011). Buhuth Fi Fiqh Qadhaya Al-Zakat Al-Mu'asirah. Dar Al-Basyar Al-Islamiyyah.

Bouheraoua, S. (2012). Zakat Obligations on Islamic Financial Institutions . International Shariah Research Academy (ISRA) Research Paper, No. 3

Hassan, A. (2013). Who needs to pay zakat: a focus on legal entities. The paper presented at National Business Zakat Symposium, Hotel Istana.

Hassan, H., Abdul Ghadas, Z. A., \& Abdul Rahman, N. (2012). The Myth of Corporate Personality: A Comparative Legal Analysis of the Doctrine of Corporate Personality of Malaysian and Islamic Laws. Australian Journal of Basic and Applied Sciences , 6(11): 191-198.

Meng, C. W. (2017). Essential Company Law in Malaysia. Malaysia: Sweet \& Maxwell.

Mohamad, A. H. (2012). Obligation of Companies to Pay Zakat: Issues Arising from Effects of Separate Legal Entity. The Law Review 2012.

Mohamad, A. H. (2012). Obligation of Companies to Pay Zakat: Summary of My Findings and My Views, https://www.tunabdulhamid.my/index.php/speech-paperslectures/item/482-obligation-of-companies-to-pay-zakat-summary 
Mohamed, A. H., \& Trakic, A. (2013). Critical Appraisal of the Companies' Obligation to Pay Zakat in the Malaysian Context. International Company and Commercial Law Review, 375-381.

Nyazee, I. A. (1997). Islamic Law of Business Organization: Partnership. Islamabad, Pakistan: International Institute of Islamic Thought and Islamic Research Institute.

Nyazee, I. A. (2010). Islamic Law of Business Organizations: Corporation. New Delhi, India: Adam Publishers \& Distributors.

Uthmani, M. T. (2008). An Introduction to Islamic Finance. New Delhi, India: Idara Isha'at E-Diniyat $(\mathrm{P})$.

Zuryati, Zainal A., Yusoff M., \& Azree A. N. (2009). Separate legal entity under Syariah Law and its aplication in Islamic banking in Malaysia. International Journal of Banking and Finance, Vol. 6: Iss. 2, Article 8. 